\title{
ДРОБЛЕНИЕ БИЗНЕСА КАК УГРОЗА НАЛОГОВОЙ БЕЗОПАСНОСТИ ГОСУДАРСТВА
}

\author{
(c) 2019 Лагутина Лариса Геннадьевна \\ кандидат экономических наук, кафедра экономической безопасности \\ Российская академия народного хозяйства и государственной \\ службы при Президенте РФ, Россия, Москва \\ E-mail: larisalagutina@mail.ru
}

Сегодня не теряет актуальность проблема минимизации предприятиями налоговых платежей, перечисляемых в бюджет Российской Федерации. Данная статья посвящена рассмотрению одной из схем налоговой оптимизации - схемы дробления бизнеса и особенностям организации системы налогового контроля по ее выявлению в целях обеспечения налоговой безопасности государства.

Ключевые слова: дробление бизнеса, малый бизнес, налогообложение, налоговый контроль, налоговая безопасность, налоговая оптимизация.

Важной компонентой экономической безопасности является система налоговой безопасности.

Налоговая безопасность - это состояние налоговой системы, при которой обеспечивается гарантированная защита налоговых интересов бизнеса, личности, общества и государства от внутренних и внешних угроз [1].

Критерием налоговой безопасности является способность налоговой системы реализовывать свои функции, одной из которых является фискальная. Эффективность осуществления фискальной функции определяет размер финансовых ресурсов государства, их пополнение, а сбалансированность и достаточность бюджетов обеспечивает возможности государства полноценно осуществлять свои функции.

Приказом ФНС России от 13.12.2018 г. N MMB-7-1/803@ «Об утверждении Стратегической карты ФНС России на 2019-2023 годы» сформулирована миссия ФНС России, которая заключается в обеспечении соблюдения законодательства о налогах и сборах, эффективной контрольно-надзорной деятельности и высоком качестве предоставляемых услуг для законного, прозрачного и комфортного ведения бизнеса, обеспечения соблюдения прав налогоплательщиков и формирования финансовой основы деятельности государства.

Успешное выполнение данной миссии связано с реализацией задач, направленных на снижение (предотвращение) угроз налоговой безопасности. Одной из таких задач является противодействие уклонению от уплаты нало- гов, в том числе за счет развития аналитических инструментов выявления налоговых правонарушений.

Проблема сокрытия налогоплательщиками доходов от налогообложения, а также оптимизация налоговой нагрузки с целью уменьшения своих налоговых обязательств перед бюджетом не теряет свою актуальность на протяжении нескольких десятилетий.

В настоящее время на уровне Правительства РФ уже предприняты немало успешных попыток по решению этих проблем, в частности достигнут рост эффективности камеральных и выездных проверок за счет внедрения риск-ориентированного подхода. На сегодняшний день одним из приоритетных направлений налогового контроля является выявление налогоплательщиков, оптимизирующих налоговую нагрузку путем применения схемы «дробление бизнеса».

Налоговая оптимизация - это комплекс мероприятий, направленных на уменьшение налоговых платежей. Она позволяет увеличить прибыль налогоплательщика, в также развивать производство, повышать конкурентоспособность, без чего невозможно функционирование предприятия в рыночной экономике.

Суть схемы «дробления бизнеса» заключается в создании ряда самостоятельных структур, подведомственных одной организации, по сути, осуществляющих деятельность одного налогоплательщика. Зачастую в созданных в ходе дробления организациях обеспечивается применение специальных налоговых режимов налогообложения, таких как упрощенная система 
налогообложения и уплата налога в виде единого налога на вмененный доход, что в итоге позволяет снизить налоговую нагрузку на группу лиц. Результатом такой оптимизации является снижение налоговых платежей в бюджетную системы РФ. Именно это обстоятельство вызывает повышенный интерес налоговых органов.

Помимо фискальной, другой немаловажной функцией налоговой системы является регулирующая функция.

Регулирующая функция проявляется через комплекс мероприятий в сфере налогообложения, направленных на усиление влияния государства на экономические процессы, осуществляя таким образом стимулирование развития отдельных сфер и отраслей экономики. Сущность регулирующей функции заключается в снижении налогового давления путем предоставления налогоплательщикам обоснованной системы льгот и преференций, компенсирующих возникающие у них потерь в связи с осуществлением ими хозяйственной или иной деятельности, обеспечивая благоприятные условия для экономической деятельности. То есть государство отказывается от части средств налогоплательщиков, направляемых в бюджет в виде налогов, обеспечивая возможность их перенаправления на развитие осуществляемой деятельности.

Поддержка малого и среднего бизнеса осуществляется путем введения в налоговое законодательство специальных режимов налогообложения.

K специальным режимам налогообложения, применяемым юридическими лицами, в частности, относятся:

- упрощенная система налогообложения (глава 26.2 НК РФ);

- система налогообложения в виде единого налога на вмененный доход для определенных видов деятельности (глава 26.3 НК РФ).

В своем письме от 29 декабря 2018 г. N ЕД-42/25984 ФНС России отмечает, что налоговые преимущества в форме специальных налоговых режимов установлены только для малого бизнеса и по своей сути призваны создать равные конкурентные условия для всех участников рынка, а злоупотребление такими преимуществами нивелируют усилия государства по налоговой поддержке малого бизнеса.

Поэтому применение специальных налоговых режимов с целью минимизации налоговых платежей, налоговыми органами признается как схема уклонения от налогообложения.

В то же время необходимо отметить, что процедура дробления деятельности налогоплательщика осуществляется в соответствии с действующими нормами гражданского права. Реорганизация юридического лица в форме разделения или выделения, осуществляемая по решению учредителей (участников) или органов юридического лица, предусмотрена статьей 57 Гражданского кодекса Российской Федерации. При этом налогоплательщику предоставлено право самостоятельного выбора применяемого режима налогообложения.

В письме от 31.10.2017 № ЕД 4-9/22123@ ФНС России подчеркивает, что положения налогового законодательства не ограничивают само право налогоплательщиков проводить свои хозяйственные операции так, чтобы налоговые последствия были минимальными, однако в избранном налогоплательщиком варианте сделки (операции) не должно присутствовать признака искусственности, лишенной хозяйственного смысла. Кроме того, налоговый орган не вправе настаивать на том, что налогоплательщик должен был выбрать тот или иной вариант построения хозяйственных операций.

Очевидно, что налоговые органы не должны игнорировать факт наличия объективных причин дробления бизнеса. Прежде всего, это оптимизация бизнес-процессов. Управление организацией в случае осуществления нескольких видов деятельности окажется более эффективным, если учет финансовых результатов будет вестись отдельно. Разделение позволит упростить не только учетные процедуры, но и процесс принятия управленческих решений в отношении оптимизации затрат предприятия, а также учитывать специфику деятельности в принятии управленческих решений.

В связи с этим перед налоговыми органами стоит задача осуществление контрольно-аналитической работы в отношении налогоплательщиков, применяющих схему искусственного дробления с целью сокращения налоговой нагрузки, избегая необоснованных претензий к разделению бизнеса, не направленному на такие злоупотребления.

Основным аргументом налогового органа в признании применения налогоплательщиком схемы дробления бизнеса является получение необоснованной налоговой выгоды.

Впервые критерии необоснованной нало- 
говой выгоды были сформулированы в Постановлении Пленума Высшего Арбитражного Суда РФ от 12 октября 2006 г. N53 «Об оценке арбитражными судами обоснованности получения налогоплательщиком налоговой выгоды». Так, налоговая выгода может быть необоснованной, если:

- в целях налогообложения операции учтены не в соответствии с их действительным экономическим смыслом;

- операции не обусловлены разумными экономическими или иными причинами (целями делового характера).

Важно обратить внимание, что в указанном Постановлении отмечено, что возможность достижения того же экономического результата с меньшей налоговой выгодой, путем совершения других предусмотренных или не запрещенных законом операций, не является основанием для признания налоговой выгоды необоснованной, но она может быть признана таковой в случае наличия доказательств того, что главной целью деятельности являлось получение дохода исключительно или преимущественно за счет налоговой выгоды в отсутствие намерения осуществлять реальную экономическую деятельность.

Правовое поле деятельности налоговых органов в части сбора доказательств получения налогоплательщиком необоснованной налоговой выгоды формируют следующие положения.

Во-первых, статья 54.1 Налогового Кодекса РФ (далее - НК РФ), вступившая в силу 19.07.2017 г., в соответствии с которой не допускается уменьшение налоговой базы, а также суммы уплачиваемого налога в результате искажения сведений о фактах хозяйственной жизни или об объектах налогообложения. Так, налогоплательщик вправе уменьшить налоговую базу и (или) сумму подлежащего уплате налога при соблюдении одновременно следующих условий:

- основной целью совершения сделки (операции) не являются неуплата или неполная уплата налога, а также его зачет или возврат;

- обязательство по сделке (операции) исполнено лицом, являющимся стороной договора, заключенного с налогоплательщиком, и (или) лицом, которому обязательство по исполнению сделки (операции) передано по договору или закону.

Во-вторых, методические рекомендации «Об исследовании и доказывании фактов умышлен- ной неуплаты или неполной уплаты сумм налога (сбора)», разработанные Следственным комитетом Российской Федерации и ФНС России (письмо ФНС России от 13.07.2017 № ЕД-4-2/13650@).

В указанных рекомендациях в качестве доказательств получения необоснованной налоговой выгоды указываются такие обстоятельства, как осуществление всеми организациями, образовавшиеся в ходе дробления, одного вида деятельности, нахождение всех организаций по одному юридическому адресу, использование одних и тех же помещений, единой материально-технической базы, единый персонал. Зачастую в случае приближения получаемых доходов в одной из организаций группы взаимозависимых лиц к предельно допустимому размеру для применения упрощенной системы налогообложения договоры с заказчиками либо расторгаются, либо заключаются дополнительные договоры с другой взаимозависимой организацией на тех же условиях.

В-третьих, письмо ФНС России от 11.08.2017 N CA-4-7/15895@, в котором приведены общие признаки, свидетельствующие о согласованности действий участников схем дробления бизнеса с целью ухода от исполнения налоговой обязанности.

Доказывая применение группой налогоплательщиков схемы дробления бизнеса, налоговый орган должен установить, что основной целью заключения налогоплательщиком сделки (операции) являлось получение налоговой выгоды, налоговые органы должны доказать, что такая сделка (операция):

- не имеет какого-либо разумного объяснения с позиции хозяйственной необходимости ее заключения и совершения,

- имеет своей целью лишь уменьшение налоговых обязательств, и (или) является частью схемы, основной целью которой является уменьшение налоговых обязательств [2].

При этом в актах и решениях по результатам налоговых проверок налоговые органы должны не только указать обстоятельства, свидетельствующие об искусственном создании условий для применения специального налогового режима и получении в связи с этим экономических выгод. Также налоговые органы должны указывать конкретные действия должностных лиц налогоплательщика, которые обусловили совершение правонарушения, и привести доказательства, которые бы свидетельствовали о на- 
мерении причинить вред бюджету.

Если в ходе налоговой проверки налоговому органу удастся доказать умышленность действий налогоплательщика, то высока вероятность доначисления налога на прибыль и налога на добавленную стоимость исходя из показателей деятельности всех участников данной «схемы», а также пересчет страховых взносов без применения понижающих коэффициентов, а также пеней и штрафов. Это несет высокий риск финансовых потерь. А в случае причинения крупного ущерба бюджету материалы проверки могут быть переданы в правоохранительные органы с целью возбуждения уголовного дела и привлечения виновных лиц к уголовной ответственности.
Таким образом, можно говорить об изменение подхода к организации налогового контроля в отношении налогоплательщиков, реализовавших схему дробления бизнеса. Этот подход находит поддержку в суде, о чем свидетельствует немало соответствующих решений, например, постановление Арбитражного суда Поволжского округа от 15 апреля 2016 г. NФ06-7410/16 по делу NA12-15531/2015, постановление Арбитражного суда Дальневосточного округа от 08.08.2018 № Ф03-3132/2018 и другие. Такая поддержка обусловлена объективными обстоятельствами, так как получение необоснованной экономической выгоды ограниченным кругом лиц несет угрозу экономической безопасности государства.

\section{Библиографический список}

1. Баженов А.А., Мехдиев Ш. З. Налоговая безопасность как элемент национальной безопасности государства // Национальная безопасность / nota bene. 2012. № 5 (22). C. 85-89.

2. Письмо ФНС России от 31.10.2017 № ЕД 4-9/22123@ «О рекомендациях по применению положений статьи 54.1 Налогового кодекса Российской Федерации». 